\title{
The Existence of the Right to Books for Frontier, Outermost and Disadvantaged Regions as Part of the Right to Enjoy Education
}

\author{
Sunardi Purwanda ${ }^{1}$ Musakkir $^{2}$ Juajir Sumardi ${ }^{2}$ Anshori Ilyas ${ }^{3}$ \\ 1.Doctoral Student, Faculty Of Law, Hasanuddin University, Indonesia \\ 2.Professor Of Law, Faculty Of Law, Hasanuddin University, Indonesia \\ 3.Associate Professor, Faculty Of Law, Hasanuddin University, Indonesia
}

\begin{abstract}
Existence refers to something that is real with certain characteristics. In general, the existence of the right to books is part of the right to enjoy education in the International Covenant on Economic, Social and Cultural Rights (ICESCR). Countries that ratify the covenant are automatically required to provide educational needs, such as books and libraries. Specifically, Indonesia has ratified the covenant, so it is obligated to fulfill the needs for books and libraries in all regions. In addition, Indonesia should specifically fulfill the rights to books and libraries of special groups (frontier, outermost and backward regions), but in reality, the fulfillment of this right is still centered in big cities and has not touched many frontier, outermost and backward regions. This is evident as there are many activities related to books in big cities, such as the existence of libraries, printing/publishing firms, and bookstores. This research aims to affirm the existence of the right to books for frontier, outermost and disadvantaged regions and find out the extent of the relationship between the right to books and the right to enjoy education as part of human rights.
\end{abstract}

Keywords: Existence, Right to Book, Fulfillment of Human Rights.

DOI: $10.7176 / \mathrm{JLPG} / 95-07$

Publication date:March $31^{\text {st }} 2020$

\section{A. Introduction}

T. S. Eliot once said that it is difficult to build a civilization without a culture of writing and reading. This is in line with the following principle: A developed nation is a nation that reads books; the lower the reading capacity of the community, the more difficult it is for the nation to progress.

These assumptions have been proven by the research results of John W. Miller ${ }^{1}$ and his team. According to Miller, the power of literacy, which is sometimes underestimated, is important for the success of the knowledgebased economies that define our global future. For 12 years, Miller conducted research on the function of literacy in the global era. Miller acknowledged that people's behavior towards the world of literacy became a very important factor in the success of individuals and nations in the economic field and other fields that require adequate knowledge base. For Miller, the love of literacy really determines the future of the world.

In March 2016, John W. Miller and his team published the results of their research on the level of public literacy in 200 countries but later reduced it to 61 countries. $^{2}$ The results of the study ranked Indonesia 60th out of 61 countries. As a result, Indonesia is only one level above Bostwana, an outrageous position. ${ }^{3}$

Some studies also mentioned that students' ability to read will have an impact on their academic ability, especially in the field of science, especially mathematics. Likewise, the research conducted by Jordan, Kaplan, and Hanich indicated that reading ability influences children's growth in the field of mathematics, but mathematical ability does not affect children's growth in reading. ${ }^{4}$

From the above explanations, it is apparent that the Indonesian people's interest in reading is still relatively low. This must be admitted, although there have been many objections from literacy activists who have discovered other facts on the ground.

If the government and people are serious about promoting literacy, especially the fulfillment of the right to books, then the country would move towards advancing the basic rights of education. In Indonesia, to fulfill the education needs of the nation's children, the founding father formulated four state goals, one of which is to educate the nation's life. ${ }^{5}$

In addition to the requirement for children to attend primary education at school, the government has also begun to seriously address student literacy matters at school, such as reading and writing matters. This is also

\footnotetext{
${ }^{1}$ John W. Miller is a researcher who studies the issue of community reading levels. In March 2016, the results of his research, titled World's Most Literate Nations, were released by Central Connecticut State University.

${ }^{2}$ Trimmed due to lack of valid information from 139 countries.

${ }^{3}$ The top five positions with the highest level of interest in reading are occupied by Scandinavian countries, starting from Finland to Norway, Iceland, Denmark and Sweden. Indonesia even performed worse than neighboring countries in Southeast Asia, such as Thailand (in position 59), Malaysia (in position 53), and Singapore (in position 36). http://webcapp.ccsu.edu/?news=1767\&data

${ }^{4}$ Jordan et al. (2002). Achievement of Growth in Children with Learning Difficulties in Mathematics, 94(3), 586-597.

${ }^{5}$ This sentence can be read in the preambule of the 1945 Constitution of the Republic of Indonesia, as one of the four objectives of the country.
} 
stated in Article 4 of Law No. 20 of 2003 concerning the National Education System, which stipulates that education is carried out by developing a culture of reading, writing and arithmetic for all citizens.

The desire of the state to promote reading and writing culture (literacy) among citizens is interesting. This issue actually surfaced in the past decade and became more intense after the issuance of Law No. 3 of 2017 concerning Book Systems. This regulation was published for the sake of developing literacy (especially in relation to books), which is useful in enhancing people's reading culture.

So far, the government in fulfilling the right to education (book affairs) has concentrated on several big cities, indicated by the number of libraries and bookstores that are accessible to the public in such cities. The inequality in accessing books among the regions of Indonesia has resulted in an imbalance of knowledge between "advanced" and "underdeveloped" regions. Therefore, tactical and effective steps should be taken by the government to reach the outermost and disadvantaged regions.

The reading interest can increase with the presence of books in the community, especially if the books are widely circulated and are accessible to the public. Some questions should be asked: What don't Indonesian people like reading? Is it due to lack of books, the culture of watching TV or is it more related to devices with various social media features? These questions can be answered by the presence of books in the community. The purposes of this research are to affirm the existence of the right to books for frontier, outermost and disadvantaged regions and to find out the extent of the relationship between the right to books and the right to enjoy education as part of human rights.

\section{B. Method}

The research method used is normative legal research involving the statutory approach. The study involves literature review and documentation, followed by qualitative analysis based on primary (legislations) and secondary legal materials (library materials and scientific journals).

\section{The Existence of the Right to Books for Frontier, Outermost and Disadvantaged Regions as Part of the Right to Enjoy Education}

Existence talks about the presence of something with certain characteristics. In general, the existence of a "right" is basically for protection. The existence of rights aims to protect humans. They are called human rights because of their nature of offering protection to humans. ${ }^{1}$ The recognition of human rights helps the fate and continuous existence of humans. Human rights are "shields" against acts or treatment of discrimination and abuse of humans by other humans.

In relation to the existence of the right to books, the characteristics of a right should be observed first. This is to make it easier to answer ${ }^{2}$ questions such as the following: Does the right to books fall into the category of "individual" or "collective" rights? Is the right "absolute" or "relative"? Is it an "interest in the law" or does it come from a "confession"? Besides, it also functions to determine the position of the right to books, whether it is a political or civil right or if it enters into the realm of social, cultural and economic rights.

The division of human rights into generations was introduced by Karel Vasak in his article titled, A 30-year Struggle; the sustained efforts to give force of law to the UDHR. Basically, there are four generations of human rights. The first generation ${ }^{3}$ includes issues related to civil and political rights. The second covers social, economic and cultural rights. The third is related to issues of development, a sense of peace, a clean and healthy environment, natural wealth and cultural heritage, and the fourth is related to development, which is based on the idea that human rights issues are not to be understood only in the context of vertical power relations but also includes horizontal relations between community groups. ${ }^{4}$

The influences of "West" and "East" greatly influenced the two early generations of human rights. Satjipto Rahardjo gave a description of the West and East camps while viewing the positions of the two generations of human rights as part of the struggle of thought of each camp. For Satjipto, not all nations and communities have the same cosmology, world outlook and society as the West. The tendency of the West, with its individual views, is certainly different from the East, which tends to be collective. Eastern culture is exemplified by Japan, with

\footnotetext{
${ }^{1}$ Wignjosoebroto, Soetandyo. (2005). Hak Asasi Manusia Konsep Dasar dan Perkembangan Pengertiannya dari Masa ke Masa, Lembaga Studi dan Advokasi Masyarakat ELSAM, Jakarta, p. 1. Also compare with Franz Magnis Suseno's view that the right to exist is not due to a gift by any powerful organization, or a gift from society, or the good of the state but is based on dignity as a human being. Suseno, Franz Magnis. (2001). Etika Politik; Prinsip-prinsip Moral Dasar Kenegaraan Modern, PT Gramedia Pustaka Utama, Jakarta, p. 121.

${ }^{2}$ Responding to these cases, of course it is not unthinkable that the history of human thought shapes and gives birth to human rights values. Therefore, these values are changing and have even been generated as a holistic discourse of the world community. According to Satjipto, the human rights generation is divided into three. See the writings of Satjipto Rahardjo, "Hak Asasi Manusia dalam Masyarakatnya". Muladi (ed). (2009). Hak Asasi Manusia; Hakekat, Konsep dan Implikasinya dalam Perspektif Hukum dan Masyarakat, Refika Aditama, Bandung, p. 219220 .

${ }^{3}$ According to Majda El Muhtaj, this first generation of human rights is defined as being negative (freedom from) rather than positive (right to). That means human rights are understood as state abstention in the search for human dignity. Muhtaj, Majda El. (2008). Dimensi-dimensi HAM; Mengurai Hak Ekonomi, Sosial, dan Budaya, Raja Grafindo Persada, Jakarta, p. 22-23.

${ }^{4}$ Ashri, M. (2008). Gugatan Warga dan Tanggung Jawab Negara dalam Pemenuhan Hak Atas Pendidikan, $5(2), 78$.
} 
people who are social in character and will only survive if they are in their community. ${ }^{1}$

The existence of cultural ${ }^{2}$ differences (including ideology), of course, has implications for the values of rights in a consensus, such as the determination of the rights in the collective agreement of the contents of the Universal Declaration of Human Rights (UDHR) approved by the states parties. This implication certainly "seeps" also into various covenants as well as national conventions and legal arrangements for ratifying countries.

The existence of the right to books - inseparable from the library - is part of fulfilling the right to enjoy education, as contained in Article 13 (2) of the 1999 International Covenant on Economic, Social and Cultural Rights (ICESCR) on the Right to Enjoy Education. ICESCR consists of 5 Sections and 31 Articles. This Covenant was agreed upon through General Assembly Resolution 220 A (XXI) on 16 December 1966. ICESCR was born from the strong impulse and desire of the global community for more complex aspects - not just individual interests - which include economic, social, and cultural rights (ESC rights). ${ }^{3}$ In the ICESCR consideration, the following was determined:

"In accordance with the principles announced in the Charter of the United Nations, the recognition of essential dignity and of equal and undeniable rights of all members of humanity is the basis of world freedom, justice and peace."4

The phrase "... of all members of humanity ..." seeks to emphasize the position of economic and social rights as a "collective right" of the global society that involves and activates the role of the state (non-abstention) $)^{5}$ in protecting human dignity. ${ }^{6}$ The characteristics of economic and social rights are different from those of civil and political rights based on the International Covenant on Civil and Political Rights (ICCPR). This is due to the tendency of individualistic political rights and the profound influence of liberal individualism and the laissez-faire social economic doctrine that was dominantly preached by reformers in the 17th and 18th centuries in Europe.

According to Saldi Isra, individual rights are the rights of every individual human. This right is constituted by the phrase "every person". Everyone means anyone. ${ }^{7}$ The position of individual rights regarding the involvement of the state is that it must avoid interfering with individuals in realizing their negative rights (religious rights, association, expressing opinions, etc.). However, the position of collective right is that the state's involvement is binding, and the state must recognize and meet the needs of citizens for the unity of the members of society. ${ }^{8}$

Is the right to books an individual or collective right? The right to books is a collective right. This answer is based on the scope of the second generation of human rights related to the involvement of the state in managing the economic, social and cultural aspects of its people. The state is demanded not to abstain from or neglect the fulfillment of economic and social rights, especially those concerning the fulfillment of education, including the provision of infrastructure in the form of libraries and the books in it.

The nature of rights, as explained earlier (individual and collective), also influences the form of the right to books. Is the right to books absolute or relative? Also, is the right to books an "interest in the law" (non-state abstention) or present from an "acknowledgment" (state abstention)?

Agus Santoso defines absolute right as a right that applies to everyone or, in other words, a right that can be defended by anyone, while relative rights are rights that apply to certain people only..$^{10}$ Absolute right is inherent in its individual nature with the characteristic "for everyone", while relative right is inherent in its collective nature, with the characteristic "applies to certain people". According to Saldi Isra, the phrase "certain people" means special groups, such as customary law communities and vulnerable groups (women, children, and people with disabilities). ${ }^{11}$ In addition, these two forms of rights are basically born of an "interest". Satjipto Rahardjo explained that interests are targets of rights, not only because they are protected by "law" but also because of "recognition". And, the target of that right is for humans, not others. ${ }^{12}$

\footnotetext{
${ }^{1}$ Muladi (ed). (2009). Op.Cit., p. 220-221.

${ }^{2}$ Culture is a symbolic aspect of social life, which includes expressions about what is right, what should be, what is wrong, what is appropriate and inappropriate. Musakkir. (2013). Putusan Hakim yang Diskriminatif dalam Perkara Pidana; Suatu Tinjauan Sosiologi Hukum dan Psikologi Hukum, Rangkang Education, Yogyakarta, p. 31-32.

${ }^{3}$ Isra, Saldi. (2014). Peran Mahkamah Konstitusi dalam Penguatan HAM di Indonesia, 11(3), 413.

${ }^{4}$ Considerations "weighing" ICESCR (Indonesian translation).

${ }^{5}$ This second generation was heavily influenced by the socialist views of the Saint-Simon group in France in the 19th century. For this group, the state must participate (non-abstention), even if necessary intervention, in order to realize social equality (claims to social equality).

${ }^{6}$ Compare also with the views of Syed, H.M. (2003). Human Rights, the Global Perspective, Reference Press, New Delhi, p. 11.

${ }^{7}$ Isra, Saldi. Loc.Cit.

${ }^{8}$ Bertens, K. (2001). Etika, Gramedia Pustaka Utama, Jakarta, p. 187-188.

${ }^{9}$ Robert Audi divides the development of human rights studies into two forms of rights, namely natural rights and legal rights. The two rights are explained as follows: natural rights are inherently enduring to their owners (inalienable rights), and legal rights can be withdrawn or transferred in accordance with the provisions of lawmakers (most fundamental rights). But basically, the two rights are complementary. Natural rights need formal legality, while legal rights need a fundamental philosophical framework. Muhtaj, Majda El. (2015). Hak Asasi Manusia dalam Konstitusi Manusia, Kencana Prenada Media Group, Jakarta, p. 36.

${ }^{10}$ Santoso, Agus. (2015). Hukum, Moral, \& Keadilan; Sebuah Kajian Filsafat Hukum, Prenadamedia Group, Jakarta, p. 125.

${ }^{11}$ Isra, Saldi. Loc.Cit.

${ }^{12}$ In line with the basic idea of Satjipto Rahardjo, "law for humans, not humans for law". This is quite familiar among Tjipian (followers of
} 
For example, in Indonesia, matters relating to the right to books and libraries for certain individuals or special groups can be read in Article 10 of Law No. 3 of 2017 concerning the Book System and in Article 5 of Law No. 43 of 2007 concerning the Library. So, basically, the right to books has been positioned as a relative right with the characteristic "applies to certain people or special groups". However, the source of this right comes from the influence of "interests derived from the law" because certain individuals or special groups have privileges that require more attention from the state, and such privileges must be regulated exclusively. That exclusivity refers to the form of rights relative to a group. But it is noteworthy that the status of exclusivity does not always exist in a country or nation. Because of its relative shape, it is necessary for the law to set its limits specifically. So, "relative" in this case is the same as the dynamic situation of the social condition of a community in a country since its status of existence can be revoked at any time.

ICESCR has positioned the right to enjoy education as part of human rights. In Article 13, Paragraph (2) of the ICESCR, the treaty parties recognize that there is an "intention to achieve" a full implementation of the right to education. The purposes to be achieved are given below:

1) Basic education must be compulsory and freely available to everyone.

2) Further education in different forms, including technical and vocational secondary education, must be generally available and easily accessible to all people, with suitable facilities, and, in particular, with a more advanced introduction to free education.

3) Higher education should be equally accessible to everyone on the basis of skills, with adequate facilities, and, in particular, with an advanced introduction to free education.

4) Fundamental education should be encouraged or intensified as far as possible for people who did not receive or complete all primary school education time.

5) The development of the school system at every level should be effectively continued; the appropriate scholarship system should be established, and the condition of teaching staff facilities should be continuously improved.

The contents of the ICESCR decree, of course, still need further elaboration. Various general comments were given in the ICESCR. General comments provide an explanation of the "intent to be achieved" regarding the rights contained in Article 13, Paragraph (2) of ICESCR, such as General Comment 13 (2) of ICESCR 1999 concerning the Right to Enjoy Education as follows:

Although the application of the terms will depend on the conditions prevailing in a particular state, all forms of education and at all levels must exhibit the following related and essential features:

a. Availability - educational institutions and programs must be available in sufficient quantities within the State's jurisdiction. What they need to function depends on many factors, including the development context in which they operate; for example, all institutions and programs tend to require building or physical protection from certain elements, sanitation facilities for both sexes, healthy drinking water, trained teachers with competitive salaries, teaching materials, and so on; some will also require facilities such as libraries, computer laboratories, and information technology.

ICESCR was officially ratified by Indonesia through Law No. 11 of 2005 on October 28, 2005. Moh. Mahfud MD stated, basically, that there is no obligation for a country to ratify international conventions or agreements. ${ }^{1}$ However, if ratified, the consequences arising from international agreements will automatically have normative powers. $^{2}$ Regarding the present discussion, such consequences require the state, as a form of its obligation to citizens, to provide all needs related to education.

Education in Indonesia cannot be separated from the needs of teaching support, which are closely related to the availability of facilities and infrastructure, including library and books. In General Comment 13 (2) of ICESCR 1999 concerning the Right to Enjoy Education, there was an affirmation of the word "library", which was as important as teaching and learning buildings, sanitation facilities, drinking water, competent teachers, and teaching materials. This confirms that the library and books ${ }^{3}$ in it have significance and must be provided by the state as an obligation in fulfilling the right to education.

In addition to ratifying the ICESCR, Indonesia also set a goal in the preamble of the country's constitution:

Satjipto thought), a study discussion group at the Faculty of Law, Diponegoro University, Semarang.

${ }^{1}$ This Covenant also completes four main agreements that have been ratified by Indonesia: CEDAW on the elimination of discrimination of women; CRC about children; CAT about torture; and CERD on the elimination of racial discrimination. The ratification certainly gave birth to a new legal situation for Indonesia. Mahfud MD, Moh. (2006). Membangun Politik Hukum; Menegakkan Konstitusi, Pustaka LP3ES Indonesia, Jakarta, p. 207.

${ }^{2}$ Ashri, M. Loc.Cit., p. 301 .

${ }^{3}$ Libraries and reading books cannot be separated from each other because libraries are indeed identical to everything related to the storage of book collections. According to Putu Laxman Pendit, this is normal because for hundreds of years since the initial development of the library, especially after the printing press was discovered, the media of books was the main collection of libraries. Pendit, Putu Laxman. (2019). References; Tradition and Sustainability, ISIPII, Jakarta, p. 35. Compare also with the definition of a library in Article 1 of Law no. 43 of 2007 concerning the Library (...is an institution that manages the collection of written works, printed works, and/or record works...) and Article 2 (library collections are all information in the form of written works, printed works, and/or recorded works in various media that has educational value, which is collected, processed, and served). In the Act, one of the works in question is a book. So the library is a medium for books. 
"...to educate the nation's life". In addition to achieving this goal, another goal to be achieved after the community becomes smart is the matter of advancing the level of welfare of citizens, because another aspect targeted by the literacy field is reducing poverty. The two objectives of the Indonesian state are in line with the concept of the rule of law adopted by various countries today, the concept of a welfare state. ${ }^{1}$

The Republic of Indonesia has an obligation to protect the human rights of citizens through legal means as stated in Act No. 39 of 1999 on Human Rights. This is based on the fact that every human being is born with something essential and universal from birth and is a gift from God Almighty. Therefore, his/her rights must be respected and maintained so as not to spoil what has been ordered. However, it is difficult to realize human rights by enforcement without legal means. Human rights cannot stand alone but needs legal means to ensure the existence of human life. Human rights are the most important in the life of the society and state; they include the various civil rights, political rights, social and cultural rights. ${ }^{2}$

Furthermore, it is also regulated in Article 28C (1) and (2), and Article 28F of the 1945 Constitution, stating that everyone has the right to develop themselves to meeting their basic needs, has the right to education and to benefit from science and technology, arts and culture, for the sake of improving the quality of life and for the welfare of humanity; advance themselves in fighting for their collective rights to develop their society, nation and country; and has the right to communicate and obtain information to develop his personal and social environment, and has the right to seek, obtain, own, store, process, convey information using all types of available channels.

In addition to the constitution, the existence of the right to books and the provision of libraries can also be found in the rules for developing a culture of reading, writing and counting for all citizens (Article 4 of Law No. 20 Year 2003 concerning the National Education System). Even more exclusive rules are mentioned in Article 10 of Law No. 3 of 2017 concerning the Book System: people in the forefront, outermost, backward, remote indigenous communities, as well as those experiencing disasters are entitled to book access services. In addition, other related provisions can also be found in Article 5 of Law No. 43 of 2007 concerning the Library: people in remote, isolated or backward areas as a result of geographical factors are entitled to special library services.

The ratification of ICESCR and the provisions contained in the 1945 Constitution and other legislations oblige the state to educate its citizens. Although this applies to everyone, more importantly, it is also meant to advance the interests of special groups (in this case, the frontier, outermost, and disadvantaged areas); such considerations were given exclusively by the law. This is a form of proportional justice, which prefers special group rights that are still often ignored by the central government. In addition, this is also meant to reduce the imbalance of the index of "knowledge" and "ignorance" between "developed" and "backward" regions.

\section{Conclusion}

The existence of the right to books is part of the right to enjoy education, which is part of human rights related to socio-economic and cultural rights. This is stipulated in Article 13, Paragraph (2) of ICESCR and is explained in more details in General Comment 13 (2) ICESCR of 1999 concerning the Right to Enjoy Education. From these provisions, it can be concluded that libraries and books are an inseparable part of the affairs of fulfilling the educational needs of citizens. In the Indonesian context, where ICESCR has been ratified, with its associated legal consequences on the part of the government, there are many libraries, printing/publishing houses, and bookstores in big cities, unlike in the frontier, outermost and backward regions, indicating that book-related activities are not evenly distributed. Of course, this will cause a gap between developed and backward regions. With reference to the right to books for communities in the frontier, outermost and disadvantaged regions, Article 10 of Law No. 3 of 2017 concerning the Book System and Article 5 of Law No. 43 of 2007 on the Library state that the government should be present to eliminate the gap between developed and disadvantaged regions and provide a sense of justice for people who are in the foremost, outermost and disadvantaged areas in order to achieve the country's goal: to educate the nation's life and advance public welfare.

\section{REFERENCES}

Ashri, M. (2008). Gugatan Warga dan Tanggung Jawab Negara dalam Pemenuhan Hak Atas Pendidikan. Jurnal Hukum Internasional-Fakultas Hukum Universitas Indonesia, 5(2), 78

Bertens, K. (2001). Etika. Gramedia Pustaka Utama. Jakarta.

Isra, Saldi. (2014). Peran Mahkamah Konstitusi dalam Penguatan HAM di Indonesia. Jurnal KonstitusiMahkamah Konstitusi, 11(3), 413.

Jordan, Nancy C., etc. (2002). Achievement Growth in Children with Learning Difficulties in Mathematics. Journal of Educational Psychology, 94(3), 586-597.

Mahfud MD, Moh. (2006). Membangun Politik Hukum; Menegakkan Konstitusi. Pustaka LP3ES Indonesia. Jakarta.

\footnotetext{
${ }^{1}$ Riza, Marwati. (2009). Perlindungan Hukum Pekerja Migran Indonesia di Luar Negeri, AS Publishing, Makassar, p. 78.

${ }^{2}$ Iin Karita Sakharina dan Handar Subhandi Bakhtiar. Custody Service of the Human Rights Perspective. Quest Journals. Journal of Research in Humanities and Social Science. Vol. 5 Issue 4 (2017). p.
} 
Muhtaj, Majda El. (2008). Dimensi-dimensi HAM; Mengurai Hak Ekonomi, Sosial, dan Budaya. RajaGrafindo Persada. Jakarta.

Muhtaj, Majda El. (2015). Hak Asasi Manusia dalam Konstitusi Manusia. Kencana Prenada Media Group. Jakarta. Muladi (ed). (2009). Hak Asasi Manusia; Hakekat, Konsep dan Implikasinya dalam Perspektif Hukum dan Masyarakat. Refika Aditama. Bandung.

Musakkir. (2013). Putusan Hakim yang Diskriminatif dalam Perkara Pidana; Suatu Tinjauan Sosiologi Hukum dan Psikologi Hukum. Rangkang Education. Yogyakarta.

Pendit, Putu Laxman. (2019). Pustaka; Tradisi dan Kesinambungan. ISIPII. Jakarta.

Riza, Marwati. (2009). Perlindungan Hukum Pekerja Migran Indonesia di Luar Negeri. AS Publishing. Makassar.

Sakharina, Iin Karita and Bakhtiar, Handar Subhandi. Custody Service of The Human Rights Perspective. Quest Journals. Journal of Research in Humanities and Social Science. Vol. 5 Issue 4 (2017). 48-51

Santoso, Agus. (2015). Hukum, Moral, \& Keadilan; Sebuah Kajian Filsafat Hukum. Prenadamedia Group. Jakarta. Suseno, Franz Magnis. (2001). Etika Politik; Prinsip-prinsip Moral Dasar Kenegaraan Modern. PT Gramedia Pustaka Utama. Jakarta.

Syed, H.M. (2003). Human Rights the Global Perspective. Reference Press. New Delhi.

Wignjosoebroto, Soetandyo. (2005). Hak Asasi Manusia Konsep Dasar dan Perkembangan Pengertiannya dari Masa ke Masa. Lembaga Studi dan Advokasi Masyarakat ELSAM. Makassar.

http://webcapp.ccsu.edu/?news=1767\&data . [accessed on 8 Juni 2019]. 